\title{
Preparation of a Model Platinum/Gamma-Alumina Catalyst for in situ Environmental TEM Experiments
}

\author{
Matthew McCann ${ }^{1}$, Henry Ayoola ${ }^{1}$, and Judith C. Yang ${ }^{1}$ \\ ${ }^{1}$ Department of Chemical and Petroleum Engineering, University of Pittsburgh, Pittsburgh, PA (USA)
}

Platinum/gamma-alumina $\left(\mathrm{Pt} / \gamma-\mathrm{Al}_{2} \mathrm{O}_{3}\right)$ is an important catalyst system used in a variety of industrial applications, such as fuel cells, petroleum reformers, and catalytic converters [1]. Correlating theoretical and experimental studies of $\mathrm{Pt} / \gamma-\mathrm{Al}_{2} \mathrm{O}_{3}$ has been hindered by the non-uniform crystallinity of commercially available $\gamma-\mathrm{Al}_{2} \mathrm{O}_{3}$ [2]. Synthesizing a well-defined, model system of $\mathrm{Pt} / \gamma-\mathrm{Al}_{2} \mathrm{O}_{3}$ is crucial for bridging the gap between experiment and theory by enabling direct comparison of experimental results and theoretical simulations [3]. In this work, we present our synthesis of a model catalyst consisting of a single-crystal, defect free $\gamma-\mathrm{Al}_{2} \mathrm{O}_{3}$ thin film decorated with well-defined Pt nanoparticles evenly dispersed on the $\gamma-\mathrm{Al}_{2} \mathrm{O}_{3}$. Cross-sectional TEM samples made from the model system will be employed for in situ environmental transmission electron microscopy (ETEM) experiments, since observing $\mathrm{Pt} / \gamma-\mathrm{Al}_{2} \mathrm{O}_{3}$ during reaction under relevant gas and thermal conditions is crucial to understanding the important structural features impacting the catalytic activity of the Pt nanoparticles.

Defect-free, single-crystal $\gamma-\mathrm{Al}_{2} \mathrm{O}_{3}$ (111) was synthesized through controlled oxidation of single-crystal $\mathrm{NiAl}$ (110) [2], the orientation of which was verified by X-ray diffraction (XRD). The NiAl surface was then polished through mechanical grinding techniques to promote homogenous growth of defect-free $\gamma$ $\mathrm{Al}_{2} \mathrm{O}_{3}$ (111) with root mean squared (RMS) surface roughness of $5.21 \mathrm{~nm}$, as measured using atomic force microscopy (AFM). The NiAl was then oxidized in a tube furnace at $750^{\circ} \mathrm{C}$ for two hours in dry air. The resulting single-crystal $\gamma-\mathrm{Al}_{2} \mathrm{O}_{3}$ was determined to be of the (111) orientation via XRD, and the surface roughness was measured by AFM to be less than 6 nm RMS (Figure 1a).

A dual beam, focused ion beam-scanning electron microscope (FIB-SEM) was used to prepare a crosssection from the sample, exposing the $\mathrm{NiAl} / \gamma-\mathrm{Al}_{2} \mathrm{O}_{3}$ interface (Figure 1a). From the SEM image of the cross-section, the $\gamma-\mathrm{Al}_{2} \mathrm{O}_{3}$ layer was determined to be about $60 \mathrm{~nm}$ thick. 1-1.5 nm diameter Pt nanoparticles were then deposited onto the $\gamma-\mathrm{Al}_{2} \mathrm{O}_{3}$ surface by electron beam evaporation. A crosssectional TEM sample was made from the $\mathrm{Pt} / \gamma-\mathrm{Al}_{2} \mathrm{O}_{3} / \mathrm{NiAl}$ (Figure 2). Deposition of monodisperse, shape-controlled, $1 \mathrm{~nm}$ Pt nanoparticles prepared by the inverse micelle technique [4] onto the model $\gamma$ $\mathrm{Al}_{2} \mathrm{O}_{3}$ surface is underway.

In addition to the model catalyst, $\mathrm{Pt} / \gamma-\mathrm{Al}_{2} \mathrm{O}_{3}$ sample were prepared using commercially available polycrystalline $\gamma-\mathrm{Al}_{2} \mathrm{O}_{3}$ for comparison. Polycrystalline $\gamma-\mathrm{Al}_{2} \mathrm{O}_{3}$ powder was solution drop-cast onto a copper TEM grid, upon which 1-1.5 nm Pt nanoparticles were subsequently deposited via electron beam evaporation. In situ environmental TEM experiments are being performed on both the model and nonuniform $\mathrm{Pt} / \gamma-\mathrm{Al}_{2} \mathrm{O}_{3}$ catalysts to understand the role of the $\gamma-\mathrm{Al}_{2} \mathrm{O}_{3}$ support on $\mathrm{Pt}$ nanoparticle behavior under relevant reaction gas and heating conditions. [5] 


\section{References:}

[1] I. Levin and D. Brandon, Journal of the American Ceramic Society 8 (1998), pp. 1995-2012.

[2] Z. Zhang et al., Acta Materialia 59 (2011), pp. 5905-5916.

[3] M. Willinger, et al., Angewande Chemie International Edition 23 (2014), pp. 5998 -6001.

[4] B. Cuenya, et al., Journal of the American Chemical Society 132 (2010), pp. 8747-8756.

[5] This work was supported by the National Science Foundation (NSF) through grant CHE-1300544. The authors are grateful for technical assistance from Tan Susheng, Mike McDonald, and Matthew France of the Nanoscale Fabrication and Characterization Facility (NFCF) at the University of Pittsburgh.
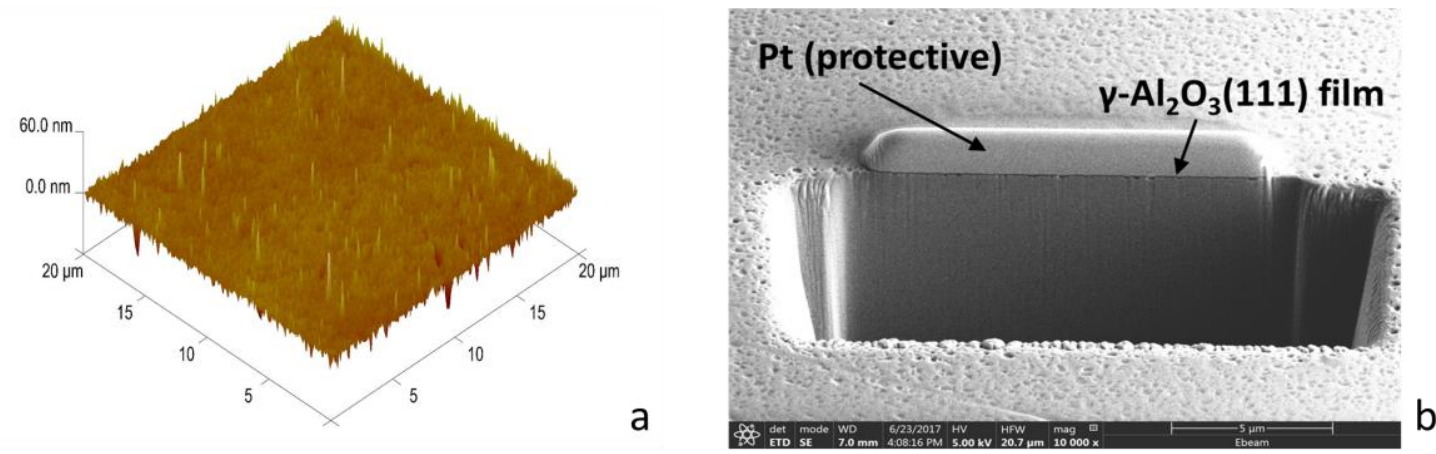

Figure 1: (a) AFM surface roughness measurement of one of the $\gamma-\mathrm{Al}_{2} \mathrm{O}_{3}$ films. (a) Cross-sectional $\mathrm{SEM}$ image of the $\mathrm{NiAl} / \gamma-\mathrm{Al}_{2} \mathrm{O}_{3}$ interface, lifted from the sample in (b).

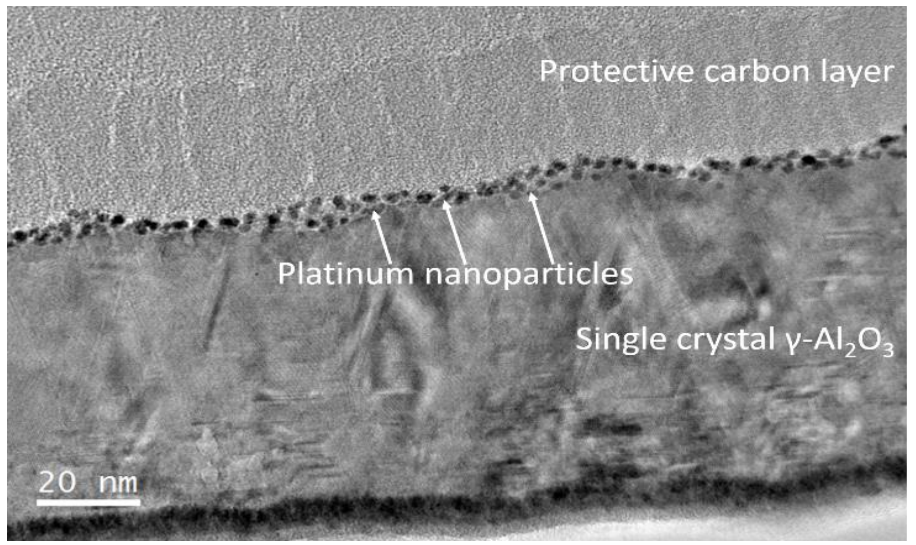

Figure 2: TEM micrograph the $\mathrm{Pt} / \gamma-\mathrm{Al}_{2} \mathrm{O}_{3}$ interface the resulting lift-out, showing the dispersion of nanoparticles across the surface. 